\title{
THROMBIN AND PROTEASE-ACTIVATED RECEPTORS IN CANCER
}

\author{
Jian Liu, Peter Schuff-Werner, and Michael Steiner \\ University of Rostock, Faculty of Medicine, Institute of Clinical Chemistry and Pathobiochemistry, \\ Rostock, Germany
}

Results from clinical studies indicate a strong association between thromboembolism and solid malignancy. Being central to blood coagulation and displaying a number of cellular postclotting activities, the serine protease thrombin has been localized within or adjacent to malignant tissues possibly associated with fibrin(oid) deposits. Thrombin proteolytically activates its cellular receptors including the prototypic protease-activated receptor 1 which is expressed by various tumor cells. Current molecular and cellular studies provide mounting evidence that the activation of protease-activated receptor(s) is the main mechanism whereby thrombin exerts its modulating effects on the malignant phenotype including tumor growth, local progression, and distant metastasis. A detailed understanding of the molecular interplay between thrombin, thrombin receptor(s) and cancer biology may be helpful to develop new therapeutic approaches consisting of the suppression of thrombin receptor(s) in malignancy.

Biomed Rev 2003; 14: 9-22.

\section{INTRODUCTION}

Cancer represents a spectrum of diseases sharing common pathobiological principles including active proliferative state due to growth signal autonomy and insensitivity to growthblocking signals, resistance to apoptosis, escape from finite replicative potential, angiogenic ability, and tissue invasion and metastasis (1). The key processes making tumor cells survive, grow aggressively and metastasize are highly complex mechanisms making its full explanation at the cellular and molecular level a challenging task. The type of tumor, different stages of its progression, and participation and regulation of a large number of gene products need to be incorporated into a steadily evolving overall picture of malignancy. In this review, we focus on the multiple implications of the serine protease thrombin and its cellular receptors as related to tumor growth, local progression, and distant metastasis.

\section{THROMBIN, HEMOSTASIS, AND CANCER}

The trypsin-like serine protease thrombin (EC 3.4.21.5) is generated by the proteolytic cleavage of its proenzyme prothrombin by coagulation factor Xa. Physiologically, thrombin generation is restricted to sites of vascular injury. The clotting activities of thrombin are central to hemostasis and include the conversion of soluble fibrinogen to insoluble fibrin occurring at even only $5-10 \mathrm{nM}$ thrombin concentration $(2,3)$. In addition, increasing attention is being paid to what is collectively referred to as thrombin's cellular or postclotting effects. These effects include proinflammatory action with stimulation of transvascular leukocyte migration, regulation of microvascular permeability with formation of interendothelial gaps, and induction of mitogenesis in fibroblasts, smooth muscle cells, and malignant cells, to name but a few (4-8).

Received 31 March 2003 and accepted 17 August 2003.

Correspondence and reprint requests to Dr Michael Steiner, University of Rostock, Faculty of Medicine, Institute of Clinical Chemistry and Pathobiochemistry, Ernst-Heydemann-Strasse 6 D-18057 Rostock, Germany. Tel.: 493814947591.

Fax: 49381 4947672, E-mail: michael.steiner@med.uni-rostock.de 
An area of growing interest is the association between thrombin and malignancy. Both clinical and laboratory evidence have shown that thrombin is implicated in the growth, progression, and metastasis of cancer. It has long been known from clinical practice that patients with solid malignancies suffer from an excess thromboembolic rate $(9,10)$. Venous thromboembolism is usually considered as a paraneoplastic syndrome complicating the natural course of cancer (11). Equally or perhaps more important, thromboembolism might actively contribute to the progression and spread of cancer. Clinical research has provided abundant evidence of a thrombophilic and/or prothrombotic state in patients suffering from a variety of malignancies including lung, colorectal, ovarian, pancreas, breast, stomach, and prostate cancer $(10,12-$ 16). For example, abnormal coagulation profiles consisting of increased levels of coagulation activation/fibrinolysis markers (prothrombin fragment $1+2$, thrombin-antithrombin complex, D-dimer) were repeatedly reported in patients with prostate cancer (16-18).

A multitude of factors, both genetic and acquired, contribute to the pathogenesis of venous thromboembolism in cancer patients (19). Host- and tumor-derived mechanisms are equally involved (Table 1 ).

Table 1. Pathogenic factors contributing to cancer-associated venous thromboembolism

- Generation of tissue factor and cancer procoagulants

- Synthesis of cytokines and growth factors

- Induction of platelet and endothelial cell activation

- Diminished fibrinolysis

- Decrease in natural anticoagulants

- Abnormal protein metabolism (dysproteinemia)

- Inflammation and acute phase response

- Hemodynamic changes

- Surgery, chemotherapy, hormone therapy

\section{LOCAL GENERATION OF THROMBIN IN TUMOR TISSUES}

The modulation of a given tumor phenotype by thrombin requires the presence of enzymatically active thrombin within or adjacent to malignant tissue. Several different methodologies have been used to approach this particularly important issue. Using immunohistochemistry, the presence of prothrombin fragment $1+2$, which is released from prothrombin during its proteolytic conversion to thrombin has been demonstrated in pancreatic, laryngeal, and prostatic cancer indicating local thrombin generation $(20,21)$. Furthermore, prothrombin was detected in pancreatic cancer cells and their stromal compartment. In addition, tumor sections stained positive for tissue factor and coagulation factors VII, X, VIII, IX and XII (22). Taken together, these data indicate that in pancreatic carcinoma extravascular blood coagulation might proceed leading to the local generation of thrombin.

A different approach using hirudin as a specific label localises thrombin to tumor cells of different origin, including small cell carcinoma of the lung, renal cancer and melanoma (23). Lung adenocarcinoma and squamous cell carcinoma are positive only in their stromal compartment. However, colon cancer sections stain negatively, lending support to the notion that the generation of thrombin by either tumor cells or tumor stroma is not a unique feature of all malignancies.

Thrombin converts soluble fibrinogen to insoluble fibrin with the formation of fibrin-rich clots retaining proteolytically active thrombin at their surface (24). This observation is highly relevant since fibrin(oid) deposits are frequently detected within and adjacent to malignant tissue of different origin and localization (25-28). Traditionally, fibrin(ogen) deposition within the tumor stroma is thought to originate from exudation of plasma fibrinogen with subsequent deposition (29). However, recent evidence indicates that certain cancer cells synthesize and secrete fibrinogen polypeptide chains suggesting endogenous synthesis and deposition within the tumor (30). The molecular composition of the tumor (neo)matrix is complex. It is best described as a transitional fibrin-containing gel with ongoing remodeling and changing organization (31). The functional impact of extravascular fibrin turnover in cancer remains to be elucidated.

In vitro experiments have shown that fibrin clot-associated thrombin can be released from the clot surface for a prolonged period of time and its ability to induce cell proliferation is fully retained (32). Due to an excess amount of antithrombin(s), thrombin activity is only short-lived in the blood circulation. However, it is tempting to speculate that enzymatically active thrombin can be steadily released from fibrin(oid) deposits within neoplastic tissue to exert its function without being inhibited by antithrombin(s). Therefore, cancer-associated fibrin clots could represent "reservoirs" of bioactive thrombin which can be released "on demand" (33). 


\section{THROMBIN RECEPTORS AND THROMBIN-BINDING SITES}

The interplay between malignancy and hemostasis including its central protease thrombin has long been recognized although the underlying molecular mechanisms were poorly understood. Recently, the identification and a steadily increasing molecular understanding of PARs provide mechanistic insight at the molecular level.

\section{The PAR family and their unique mechanism of pro- teolytic activation}

$\mathrm{G}$ protein-coupled, seven-transmembrane segment receptors (GPCRs or 7TMRs) constitute a large superfamily of proteins with exceptional ligand diversity which transmit signals from the extracellular environment to the cytoplasm predominantly by recruiting and activating heterotrimeric $\mathrm{G}$ proteins. In accordance with the traditional understanding of ligand-receptor interactions, binding of an extracellular ligand to its specific GPCR causes a conformational change and activation of the receptor followed by the generation of a series of signaling events (34). However, it was only recently that a different and unique activation mechanism of GPCR has been identified. The activation of this type of GPCR does not only depend on ligand binding to, but also on the cleavage of the receptor molecule by employing the proteolytic activity of the protease ligand. Accordingly, this family of GPCRs has been designated protease-activated receptors. Following the molecular cloning of the prototypic functional thrombin receptor (PAR-1) from a human megakaryoblastic cell line (35), a four-member family comprising PAR-1, -2, -3 and
-4 has emerged (36). Only PAR-2 is known to be activated by trypsin and additional proteases with trypsin-like specificity (37) while the other three receptors are proteolytically activated by thrombin. PAR-1 has been recently suggested to be cleaved and activated by coagulation factor Xa without the participation of thrombin in human cervical carcinoma cells (38). Although the coagulation factors VIIa and Xa activate PAR-2 (39), it is not considered a thrombin receptor and will not further be covered in this review. PAR-3 and PAR-4 are the most recently identified members of the PAR family $(40,41)$.

Thrombin recognizes and binds to the aminoterminal exodomain of PAR-1 specifically cleaving the peptide bond located between the residues Arg-41 and Ser-42. This cleavage results in a new aminoterminus ("tethered ligand") starting with the amino acid residues Ser-Phe-Leu-Leu-Arg-Asn (SFLLRN). This newly formed tethered ligand binds into the transmembrane domain of PAR-1 thus eliciting signalling events (Fig. 1). The activated PAR-1 initially internalizes via clathrin-coated pits and is then sorted away from recycling pathways and delivered to lysosomes for degradation (42). A pool of intracellular intact PAR-1 "reserve" can quickly repopulate the cell surface without the requirement of new receptor synthesis (43). Similar activation mechanisms have been described for all members of the PAR family. Several synthesized thrombin receptor activation peptides (TRAPs) comprising the corresponding tethered ligand amino acid residues are powerful experimental tools to mimic the thrombinmediated activation of protease-activated receptors. Being the prototypic member of the PAR family, PAR-1 is believed

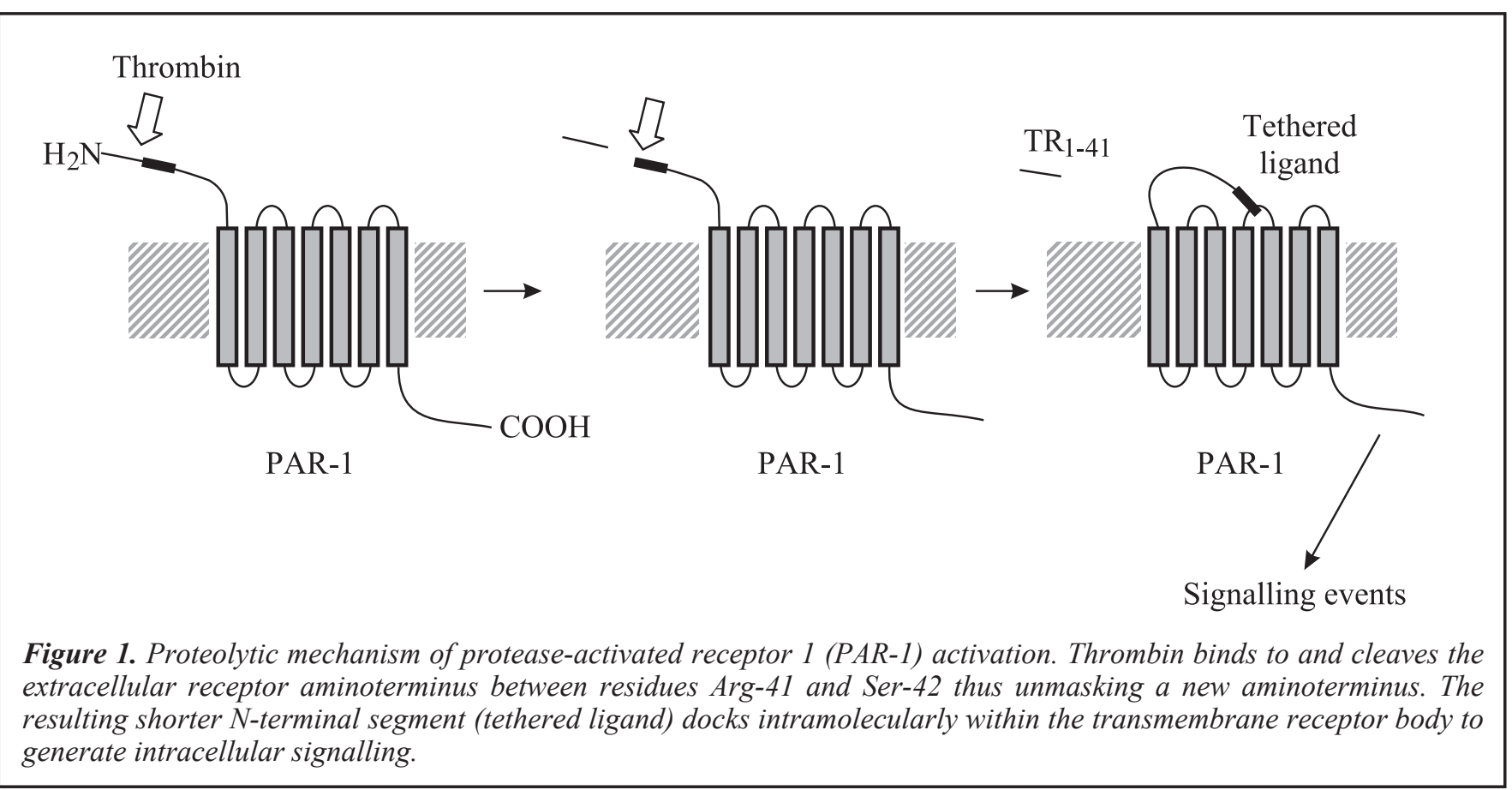


to mediate most if not all of the cellular effects exerted by thrombin, while PAR-3 may function as a tethering protein for thrombin. PAR-4 is rather insensitive to thrombin demonstrating low affinity (44).

\section{Expression profile of thrombin receptors}

Physiologically, PAR-1 is expressed by different human tissues including blood and blood vessel cells (45), and in the central nervous system (46). PAR-3 is detectable in mouse platelets, rat brain capillary endothelial cells and astrocytes, and human airway smooth muscle cells (47-49). Notably, human platelets do not express PAR-3 (36). Both PAR-1 and PAR-4 are expressed in human platelets, and either of them independently mediates thrombin signalling, PAR-1 at low while PAR-4 at high thrombin concentrations (50). It has been suggested that PAR-4 may act as a "backup" mechanism in human platelets in the absence of PAR-1 functionality. The recent development of PAR knockout mice has provided a valid approach to comprehensively elucidate the physiological and pathological importance of the different members of the PAR family (51).

The prototypic thrombin receptor PAR-1 has recently been detected in most established malignant cell lines and in a number of cancer tissues obtained from different primary origin (Table 2). It seems tempting to speculate on an association between the expression level of thrombin receptors and the tumor phenotype including differentiation and the propensity to form metastasis. For example, PAR-1 is expressed in oral squamous cell carcinomas with PAR-1 protein levels being lower in non-metastatic compared to metastatic cells (52). PAR-1 protein was not detected in the epithelia of normal pancreatic tissue whereas immunofluorescence staining and Western blot studies of pancreatic cancer cell lines revealed a correlation between PAR-1 expression intensity and the grade of differentiation. The level of mRNA ${ }^{\text {PAR-1 }}$ is lower in normal pancreas compared to pancreatic cancer tissue. The levels of mRNA ${ }^{\text {PAR-1 }}$ differ up to 25 -fold between different pancreatic cancer cell lines (53). Compared to normal prostate tissue or soft tissue metastasis-derived prostate cancer cells, prostate cancer cells derived from bone metastases express increased amounts of PAR-1 indicating an association between PAR-1 expression and bone metastases $(54,55)$. These findings support a hypothetical relationship between the level of thrombin receptor PAR-1 expression, carcinogenesis, and cancer progression.

The progression of a given tumor requires bidirectional communication with its microenvironment. PAR-1 expression has been demonstrated in stromal cells surrounding malignant tissue. Up-regulated PAR-1 expression is detected in cancer stromal fibroblasts compared to normal or benign counterparts (56) suggesting that the aberrant PAR-1 expression in and/or around tumor tissues contributes to abnormal cellular communication in malignancy.

Considerably less work has been performed to investigate the expression profile of the additional thrombin receptors PAR-3 and PAR-4 in cancer cells and tissues. However, mounting evidence suggests the presence of multiple PAR species in human malignant cells. Human astrocytoma cells express PAR-1 and PAR-4 (57). In primary human renal carcinoma cells, co-expression and cellular surface clustering of PAR-1 and PAR-3 was detected (58) pointing to receptor interactions. Similarly, a complex PAR expression profile was reported for breast cancer cells (59). Highly invasive breast cancer cells MDA-MB-231 express very high levels of functional PAR-1, PAR-4, and trypsin receptor PAR-2, while minimally invasive MCF7 cells have only trace amounts of PAR-1 and low levels of PAR-4 and PAR-2. These cell lines should be helpful to study in detail the relative contribution of the individual thrombin receptors to cellular effects exerted by thrombin. It was also demonstrated that the expression profile of thrombin receptors in a given tumor varies with the histopathological type. Table 2 summarizes the expression profile of established cell lines and primary cancer tissues except for blood-related cells (45). It should be noted that only SIT1 melanoma cells were shown not to express PAR1. Moreover, this cell line is unique in not expressing any of the thrombin receptor species identified so far (60). Partly controversial data have been obtained for PAR expression in several cell lines including MCF-7 and MDA-MB-231 breast cancer cells $(59,61-63)$, and LnCAP prostate cancer cells $(64,65)$.

\section{Additional thrombin-binding sites}

In addition to PARs, other thrombin-binding sites including thrombomodulin and glycoprotein $\operatorname{Ib} \alpha(\mathrm{GPIb} \alpha)$ are variably expressed by malignancies of different cellular origin (76,77).

Thrombomodulin (TM) is a thrombin-binding glycoprotein expressed on the luminal vascular endothelial cell surface. It is a potent negative coagulation regulator acting as a molecular switch by converting thrombin from a procoagulant protease to an anticoagulant (78). In addition, TM precludes thrombin from activating PAR-1 (79). Expression of TM seems to be restricted to certain types of malignancy including transitional cell (76) and squamous cell carcinoma (80), ovarian (81) and pancreatic cancer (82). Clinical studies have indicated that the expression of TM in lung squamous cell carcinoma is inversely correlated with malignancy with a decrease of TM expression being associated with metastasis and poor prognosis $(83,84)$. Potential mechanisms underlying a less aggressive tumor phenotype in TM-expressing cancer include the abrogation of thrombin procoagulant activities, reduction of pericellular thrombin concentration by its TMmediated internalization, and inhibition of PAR-1 activation. 
Table 2. Expression profile of thrombin receptors (PAR-1, PAR-3 and PAR-4) by malignant cells*

\begin{tabular}{|c|c|c|c|c|c|}
\hline & \multicolumn{3}{|c|}{ Protease-activated receptor } & \multirow{2}{*}{ Assay } & \multirow{2}{*}{ Reference } \\
\hline & 1 & 3 & 4 & & \\
\hline \multicolumn{6}{|l|}{ Established cell cultures } \\
\hline DU145 (prostate carcinoma) & $\begin{array}{ll}+ \\
+\end{array}$ & ND & ND & $\begin{array}{l}\text { RT-PCR } \\
\text { FCM } \\
\end{array}$ & $\begin{array}{l}63,65 \\
65\end{array}$ \\
\hline LnCAP (prostate carcinoma) & $\begin{array}{l}+ \\
+ \\
\end{array}$ & $\begin{array}{l}- \\
- \\
\end{array}$ & $\begin{array}{l}- \\
+ \\
\end{array}$ & $\begin{array}{l}\text { RT-PCR } \\
\text { FCM } \\
\end{array}$ & $\begin{array}{l}65 \\
64 \\
\end{array}$ \\
\hline A172 (glioblastoma) & + & ND & ND & RT-PCR & 66 \\
\hline SNB-19 (glioblastoma) & + & - & - & RT-PCR, ICC & 57 \\
\hline M24met (melanoma) & + & ND & ND & Immunofluorescence & 67 \\
\hline SK-Mel-28 (melanoma) & + & ND & ND & RT-PCR, Southern, Western & 68 \\
\hline SIT1 (melanoma) & - & - & - & Northern & 60 \\
\hline A549 (lung carcinoma) & + & + & + & RT-PCR, ICC & 69 \\
\hline O22 (laryngeal carcinoma) & + & ND & ND & Western & 52 \\
\hline Hep-2g (laryngeal carcinoma) & + & ND & ND & ICC & 70 \\
\hline $\begin{array}{l}\text { MIA PaCa-2 } \\
\text { (pancreatic carcinoma) }\end{array}$ & + & ND & ND & ICC & 71 \\
\hline MDA-MB-436 (breast carcinoma) & - & ND & ND & FCM & 62 \\
\hline $\begin{array}{l}\text { MDA-MB-435 } \\
\text { (breast ductal carcinoma) }\end{array}$ & + & ND & ND & Northern, ICC, Western & 61 \\
\hline $\begin{array}{l}\text { MDA-MB-231 } \\
\text { (breast adenocarcinoma) }\end{array}$ & $\begin{array}{l}+ \\
+ \\
+ \\
+\end{array}$ & $\begin{array}{l}+/- \\
\text { ND } \\
- \\
\text { ND }\end{array}$ & $\begin{array}{c}+ \\
\text { ND } \\
\text { ND }\end{array}$ & $\begin{array}{l}\text { FCM } \\
\text { Northern, ICC, Western } \\
\text { RT-PCR } \\
\text { FCM } \\
\end{array}$ & $\begin{array}{l}59 \\
61 \\
63 \\
62\end{array}$ \\
\hline MCF7 (breast adenocarcinoma) & $\begin{array}{c}+/- \\
-1+ \\
+ \\
-\end{array}$ & $\begin{array}{l}+/- \\
\text { ND } \\
- \\
\text { ND }\end{array}$ & $\begin{array}{c}+ \\
\text { ND } \\
- \\
\text { ND }\end{array}$ & $\begin{array}{l}\text { FCM } \\
\text { Northern, ICC, Western } \\
\text { RT-PCR } \\
\text { FCM } \\
\end{array}$ & $\begin{array}{l}59 \\
61 \\
63 \\
62 \\
\end{array}$ \\
\hline HeLa (cervical carcinoma) & $\begin{array}{l}+ \\
+ \\
\end{array}$ & $\begin{array}{c}\text { ND } \\
-\end{array}$ & $\begin{array}{c}\text { ND } \\
-\end{array}$ & $\begin{array}{l}\text { RT-PCR, Southern, Western } \\
\text { Northern }\end{array}$ & $\begin{array}{l}68 \\
38\end{array}$ \\
\hline $\begin{array}{l}\text { Tu686, 686LN } \\
\text { (oral squamous cell carcinoma) }\end{array}$ & + & ND & ND & Western & 52 \\
\hline KB (oral epidermoid cancer ${ }^{\star \star}$ ) & + & + & - & RT-PCR & 72 \\
\hline Clone A (colon adenocarcinoma) & + & ND & ND & $\begin{array}{l}\text { Nested RT-PCR, Southern, Sequencing, } \\
\text { Western }\end{array}$ & 73 \\
\hline $\begin{array}{l}\text { HCT-8, SW-48, HT-29 } \\
\text { (colon carcinoma) }\end{array}$ & + & ND & ND & RT-PCR, Southern, Western & 68 \\
\hline \multicolumn{6}{|l|}{ Primary culture or tissue } \\
\hline $\begin{array}{l}\text { Non-breast carcinoma tissue specimens } \\
\text { (gastric, lung, liver, thyroid, ovarian) }\end{array}$ & + & ND & ND & IHC, ISH & 56 \\
\hline Primary glioblastoma cells & + & ND & ND & ICC & 74 \\
\hline $\begin{array}{l}\text { Breast carcinoma } \\
\text { tissue specimens }\end{array}$ & $\begin{array}{l}+ \\
+ \\
\end{array}$ & $\begin{array}{l}\text { ND } \\
\text { ND }\end{array}$ & $\begin{array}{l}\mathrm{ND} \\
\mathrm{ND}\end{array}$ & $\begin{array}{l}\mathrm{ISH} \\
\mathrm{IHC}, \mathrm{ISH}\end{array}$ & $\begin{array}{l}61 \\
56 \\
\end{array}$ \\
\hline Oral squamous cell carcinoma & + & ND & ND & IHC, RT-PCR & 52 \\
\hline Primary renal cell carcinoma & + & + & - & RT-PCR, ICC, EM & 58 \\
\hline Pancreatic adenocarcinoma & + & ND & ND & RT-PCR, Immunofluorescence, Western & 53 \\
\hline
\end{tabular}

* Reports were only considered if direct proof of PAR expression was obtained at either the mRNA or protein level. Publications providing indirect evidence for the expression of PAR (e.g. by recording cellular phenomena after treatment with thrombin and/or TRAPs) were not included.

**The identity of KB cells as oral epidermoid cancer cells has recently been questioned (75).

Abbreviations:

RT-PCR Reverse transcription-polymerase chain reaction

ICC Immunocytochemistry

FCM Flow cytometry

IHC Immunohistochemistry

ISH In situ hybridization

EM Electron microscopy

ND Not done 
The relative importance of TM expression as related to the cellular effects of thrombin has not been conclusively established. However, it should be noted that in A549 lung cancer cells TM constitutes about $90 \%$ of all thrombin binding sites (85). In our laboratory, we demonstrated that TM is not expressed in metastasis-derived human prostatic cancer cell lines DU145 and LnCAP (unpublished data) which is consistent with the concept that reduced or absent TM expression seems favourable for thrombin-mediated PAR-1 activation with a plethora of downstream effects contributing to tumor growth and progression.

GPIb $\alpha$ forms part of the glycoprotein Ib-IX-V complex primarily expressed on the platelet surface (86). GPIb $\alpha$ contains several ligand-binding domains for von Willebrand factor (vWF), Mac-1, P-selectin, coagulation factor XII, and thrombin. Significant insight has been obtained into thrombin binding to platelet GPIb $\alpha$ suggesting that GPIb $\alpha$ may act as a cofactor for PAR-1 activation by thrombin (87). However, the effects of binding of thrombin to tumor cell surface GPIb $\alpha$ are largely unknown mainly due to the long-held belief that GPIb $\alpha$ expression is restricted to cells of megakaryocytic lineage (88). Only few studies convincingly ruled out the expression of GPIb $\alpha$ by the malignant cells under consideration (89). Although formal proof of GPIbo/thrombin interaction in malignant cells is lacking, indirect evidence has been provided. GPIb $\alpha$ has been detected in human breast cancer cell lines and primary breast tumor tissue samples. In addition, it may play an important role in tumor-induced platelet aggregation and in the hematogenous spread of breast cancer cells $(90,91)$. The functional importance of GPIb $\alpha$ expression by malignant cells and its molecular interplay with thrombin and/or PAR-1 remains to be studied.

\section{THROMBIN, PAR, AND TUMOR BIOLOGY}

At the present time, it seems premature to conclude that cellular effects evoked by the exposure of malignant cells to thrombin are exclusively mediated by the proteolytic activation of thrombin receptor(s). However, their significant contribution to tumor growth, local progression, and distant metastasis is being gradually established.

\section{Tumor progression: cell proliferation}

The mitogenic effect of thrombin on smooth muscle cells, fibroblasts, and endothelial cells has long been appreciated $(4,5,92)$. Thrombin treatment of pigment epithelial cells activates S-phase reentry in vitro (93). In interferon- $\gamma$-differentiated growth-arrested U937 promonocytic cells, the proliferation-stimulating effect of thrombin was demonstrated by downregulation of $\mathrm{p} 21^{\text {waf/cip } 1}$ and upregulation of cyclin D1 expression (94).

In addition, thrombin displays mitogenic activity towards a variety of malignancies including astrocytoma, laryngeal, colon and prostate cancer $(6,65,70,95)$. Although the molecular mechanisms involved in thrombin-mediated tumor cell mitogenesis are not yet understood in full detail, it elicits signalling events through coupling with multiple G proteins and complex signalling pathways including Ras protein, protein kinase $\mathrm{C}(\mathrm{PKC})$ and mitogen-activated protein kinase (MAPK) cascade(s). For example, thrombin treatment of $1321 \mathrm{~N} 1$ astrocytoma cells lead to polyphosphoinositide hydrolysis, $\mathrm{Ca}^{2+}$ mobilization, and DNA synthesis. Either microinjection of a dominant interfering mutant of human Ras or an inhibitory antibody against Ras into these cells inhibited DNA synthesis after thrombin treatment (6). The mitogenic activities of thrombin and PAR-1 activation peptide on human epidermoid carcinoma cells can be abolished by the PKC inhibitor bisindolylmaleimide (70). The MAPK cascade forms a critical part of the signalling mechanisms in eukaryotic cell regulation (96). Specific inhibitors for MAPK kinase or MEK suppress thrombin/PAR-1-induced cell proliferation in human colon cancer cells (95) and prostate cancer cells (Liu et al, in preparation).

Recent studies observed dose-dependent dual effects of thrombin on the proliferation kinetics of certain types of tumor cells in vitro. At low concentrations, thrombin leads to increased cell proliferation while high concentrations of thrombin cause impaired tumor cell growth and/or apoptosis $(97,98)$. Strikingly, the opposite pattern was also observed in rat C6 glioma cells with inhibition of proliferation at lower thrombin concentrations (99). Potential mechanisms underlying the different cellular proliferation kinetics in a variety of cell lines include the impact of thrombin on cell cycle control and apoptosis (98). Thrombin-induced changes in cell cycle control and apoptosis were associated with p53-independent, STAT-1-dependent up-regulation of $\mathrm{p} 21^{\mathrm{wa} / \mathrm{cip} 1}$ and caspases (63). However, inconsistent expression patterns of p53, p21 and bcl-2 in thrombin-induced apoptosis have been described (98). Preliminary evidence suggests the involvement of a variety of signaling mechanisms in the regulation of apoptosis by thrombin in malignant cells (100).

The molecular mechanisms of thrombin-induced mitogenesis and cell cycle control in malignant cells remain to be fully elucidated. Of particular importance will be the molecular dissection of apoptosis-inducing pathways triggered by thrombin at higher concentrations.

\section{Tumor progression: angiogenesis}

A solid tumor can not grow beyond a critical limit of 1-2mm in diameter without gaining access to the host circulatory system that supplies the tumor with nutrients and wastedisposal capacity. Once the primary tumor gains access to the blood-supplying system, growth at the primary site is no longer limited. Tumor-associated angiogenesis is the process of generation of new blood vessels that connect the tumor 
with the host blood vessel system. Although angiogenesis physiologically takes place in a limited number of occasions, such as embryogenesis, wound healing and the proliferative phase of the female reproductive cycle, tumor cells can initiate (neo)vascularization by secretion of an array of proangiogenic factors. Thrombin has been reported to play a critical role in triggering and sustaining tumor-associated angiogenesis (101-103).

Vascular endothelial growth factor (VEGF) is a potent proangiogenic cytokine directly acting on endothelial cells to promote new vessel formation. Up-regulation of VEGF expression and secretion by tumor cells and surrounding endothelial cells is a key aspect of tumor-associated angiogenesis (104). VEGF expression is more pronounced in human prostate cancer compared to normal prostate tissue (105). We observed that DU145 and LnCAP prostate cancer cells secrete increased amounts of VEGF in comparison to non-tumorigenic SV40-immortalized prostate epithelial cells PNT1A (unpublished data) supporting the concept that VEGF levels are related to malignancy and metastasis. Both thrombin and PAR-1 activation peptide stimulate VEGF expression and secretion from cancer cells and vascular smooth muscle cells with a dose- and time-dependent pattern $(106,107)$. The mechanism of increased expression of VEGF seems to involve stabilization of the mRNA. The increase of VEGF mRNA is inhibited by wortmannin (a PI3Kinase inhibitor) and $\mathrm{H} 7$ (a broad spectrum serine/threonine kinase inhibitor) demonstrating that PI3Kinase and serine/theronine kinase pathways are involved (106). Thrombin-induced VEGF release from vascular smooth muscle cells is significantly reduced by applying neutralizing antibodies against plateletderived growth factor (PDGF), transforming growth factor (TGF)- $\beta$, and basic fibroblast growth factor (bFGF) showing its dependence on the endogenous formation of a variety of growth factors (107). On the other hand, incubation of human umbilical vein endothelial cells (HUVEC) with VEGF accelerates tissue factor generation and the conversion of inactive prothrombin to enzymatically active thrombin (108) suggesting the functionality of a feedback system in thrombin/VEGF-stimulated tumor neovascularization. In addition, overexpression of VEGF receptors (Flt-1 and KDR) was observed in tumor blood vessel cells that also express VEGF (109). However, prostate cancer was shown to demonstrate less intense VEGF receptor expression compared to benign prostatic hyperplasia (110).

Interleukin-8 (IL-8) is another inducer of tumor neoangiogenesis $(111,112)$. IL-8 directly increases endothelial cell proliferation, survival, matrix metalloproteinases (MMP) expression, and tumor-associated angiogenesis (113). Thrombin-mediated activation of PAR-1 causes the release of IL-8 from human respiratory epithelial cells (69). However, an indirect mode of action of thrombin on IL-8 expression in tumor tissue has also been demonstrated (114). Thrombincatalyzed fibrin formation has been detected in oral squamous cell carcinoma in vivo. Although the application of thrombin had no effect on IL-8 expression in these cells, incubation with fibrin caused a dose- and time-dependent stimulation of IL- 8 expression. In contrast, a similar stimulation of IL- 8 by fibrin was not observed in non-malignant oral cells.

An important family of proteins involved in vascular development and stability has been identified and designated angiopoietins (115). It has been reported that thrombin enhances the expression and secretion of angiopoietin-2 from HUVEC. Hirudin pretreatment inhibits this cellular response showing thrombin specificity (116). There are still other metastasis-associated molecules which are regulated by thrombin. Chicken chemotactic and angiogenic factor (cCAF) being the product of the $9 E 3 / C E F 4$ gene, is a proangiogenic protein. cCAF is highly expressed in Rous sarcoma virus-induced tumor where thrombin acts as the most potent natural stimulator of 9E3/CEF4 gene (117). Platelet-activating factor (PAF) is a phospholipid mediator of inflammation and is correlated with microvessel density. PAF has been detected in breast cancer tissue and thrombin stimulates PAF production in human breast cancer cell lines. Animal experiments demonstrated that PAF receptor antagonists abolished the formation of new tumor vessels in SCID mice injected with MDA-MB231 breast cancer cells (118).

It has long been established that a number of growth factors participate in the regulation of tumor-associated angiogenesis. However, the individual functional importance of any of these factors related to the progression of a given malignancy remains unknown. Within the tumor microenvironment, thrombin-mediated activation of PAR-1 expressed by tumor cells and/or surrounding stromal cells might play a critical role in triggering and sustaining new vessel formation. Thrombin and the proangiogenic VEGF may assemble a positive feedback system to promote tumor-associated angiogenesis: VEGF induces local thrombin generation within tumor tissues, and thrombin enhances VEGF secretion thus further contributing to the vascularization of malignancy.

\section{Tumor cell adhesion, invasion, and metastasis}

Tumor cell adhesion to platelets, vascular endothelium, and extracellular matrix (ECM) is critical to tumor invasion and metastasis. Thrombin regulates the expression of various adhesion molecules in tumor cells and modulates their adhesion to endothelial cells, platelets, and ECM components including fibronectin, laminin, collagen and $\operatorname{vWF}(52,73,119,120)$. Thrombin enhances the adhesion of melanoma cells transfected with full-length PAR-1 sense cDNA to fibronectin compared to mock-transfected cells demonstrating the importance of PAR-1 in thrombin-induced cell adhesion (89).

Thrombin/PAR-1-mediated cell adhesion involves the 
up-regulation of a variety of adhesion molecules including integrin $\alpha_{v} \beta_{5}$, integrin IIb-IIIa receptor, ICAM-1, VCAM1 , and P-selectin $(119,121,122)$. Both thrombin and PAR1 activation peptide induce the expression of ICAM-1 and VCAM-1 in endothelial cells (121). Thrombin-induced tumor cell adhesion to platelets is abolished by inhibitors of platelet integrin IIb-IIIa receptor occupancy and by polyclonal antibodies directed against the integrin IIb-IIIa ligands fibronection and vWF (119). Monoclonal antibodies against the integrin IIb-IIIa and P-selectin also inhibit the effect of TRAP-activated platelets on enhancing tumor cell adhesion to endothelial cells (123).

Invasion is the passage of tumor cells through the basement membranes and their migration into the surrounding tissues, and represents a critical step in the cascade of local cancer progression and distant metastasis (124). Basement membranes are comprised of multiple components including collagens, laminins, and proteoglycans. They form tight barriers between the different tissues but may become permeable during tissue development, repair, inflammation, and tumor invasion/metastasis. The process of metastasis of a given tumor initially requires cellular detachment from the primary tumor location and degradation of the basement membrane and interstitial connective tissue. At a later stage, enhanced adhesion to stromal components is a prerequisite to form metastases at distant sites.

One well-characterized example of extracellular proteases known to be involved in invasion is the urokinase-type plasminogen activator (uPA) which converts plasminogen to plasmin. Plasmin is a broad-spectrum protease that degrades extracellular matrix components. In PC-3 prostate cancer cells, thrombin generates a dose- and time-dependent increase in uPA expression and secretion. This effect is mediated by the proteolytic activation of thrombin receptor as PAR-1 activation peptide also causes increased uPA synthesis (125). Moreover, thrombin and TRAP activate matrix metalloproteinase 2 which plays a key role in the degradation of the extracellular matrix during tumor invasion (52). In addition, thrombin enhances the heparanase-induced degradation of heparan sulfate proteoglycans in tumor stroma $(126,127)$.

Experimental evidence suggests that the levels of thrombin and its receptor are implicated in tumor invasion and metastasis (128). Metastatic human breast carcinoma cell lines and tissues express high levels of PAR-1. The introduction of PAR-1 antisense cDNA significantly inhibits the invasive potential of metastatic cells in vitro (61). Animal experiments have shown that both preinjection of thrombin or PAR-1 activation peptide into mice and pretreatment of tumor cells with thrombin significantly enhance pulmonary metastasis. It was also noted that a five-fold increase of metastasis occurred when using tumor cells transfected with PAR-1 cDNA compared to mock-transfected cells (119). In addition, inhibition studies demonstrated that blocking of the coagulation cascade at the level of thrombin diminishes hematogenous metastasis of the human melanoma cell line M24met in SCID mice confirming the importance of thrombin during tumor metastasis (67).

Tumor cell-induced platelet aggregation is considered an important step in hematogenous metastasis. Microvesicles from the cell-free supernatant of U87MG human glioblastoma cells result in platelet aggregation and coagulation with a thrombin-dependent pattern (129). A panel of human pancreatic cancer cell lines induces platelet aggregation, which can be inhibited by the addition of hirudin making the involvement of thrombin likely (130).

\section{WE ARE (ALMOST) THERE: CONCLUSIONS AND OPEN QUESTIONS}

Thrombin can be generated in malignant tissues with the capability of exerting a multitude of modulating effects on tumor cells and their stromal components. It is beyond any doubt that the prototypic thrombin receptor PAR-1 expressed by cancer cells mediates most if not all of the cellular effects of thrombin. Being involved in a given tumor phenotype including growth, angiogenesis, adhesion, invasion and metastasis, thrombin and its cellular receptor(s) significantly contribute to overall tumor biology (Fig. 2). However, due to the complexity and diversity of cancer, the molecular mechanisms of the pathogenesis of malignancy and the particular impact of the coagulation protease thrombin have not yet been worked out in detail even for a small portion of human cancers. Therefore, ongoing and future basic, translational and clinical research is expected to answer a number of open questions.

First and foremost, more and convincing in situ data need to prove the concept that malignant tissues harbor the molecular machinery to generate amounts of proteases (in particular thrombin) known from in vitro studies to have an impact on malignant cells via PAR activation. Once in place, PAR activation by thrombin generates a cleaved peptide (TR1-41) whose functional implications are largely unknown. Considering tumor biology, we need to understand if these peptides are a major culprit or just innocent bystanders.

Another set of unanswered questions relates to the molecular interplay between the major thrombin receptor PAR1 and other thrombin receptors and binding sites including PAR-3, PAR-4, thrombomodulin, and GPIb $\alpha$. Approaches allowing to manipulate gene expression such as transgenic, antisense, and gene targeting tools including tissue-specific and inducible gene-knockout, and small interfering RNA (siRNA) techniques are expected to provide molecular insight $(131,132)$.

Finally, newly designed PAR agonists and antagonists will be tested to selectively modulate tumor growth and metas- 


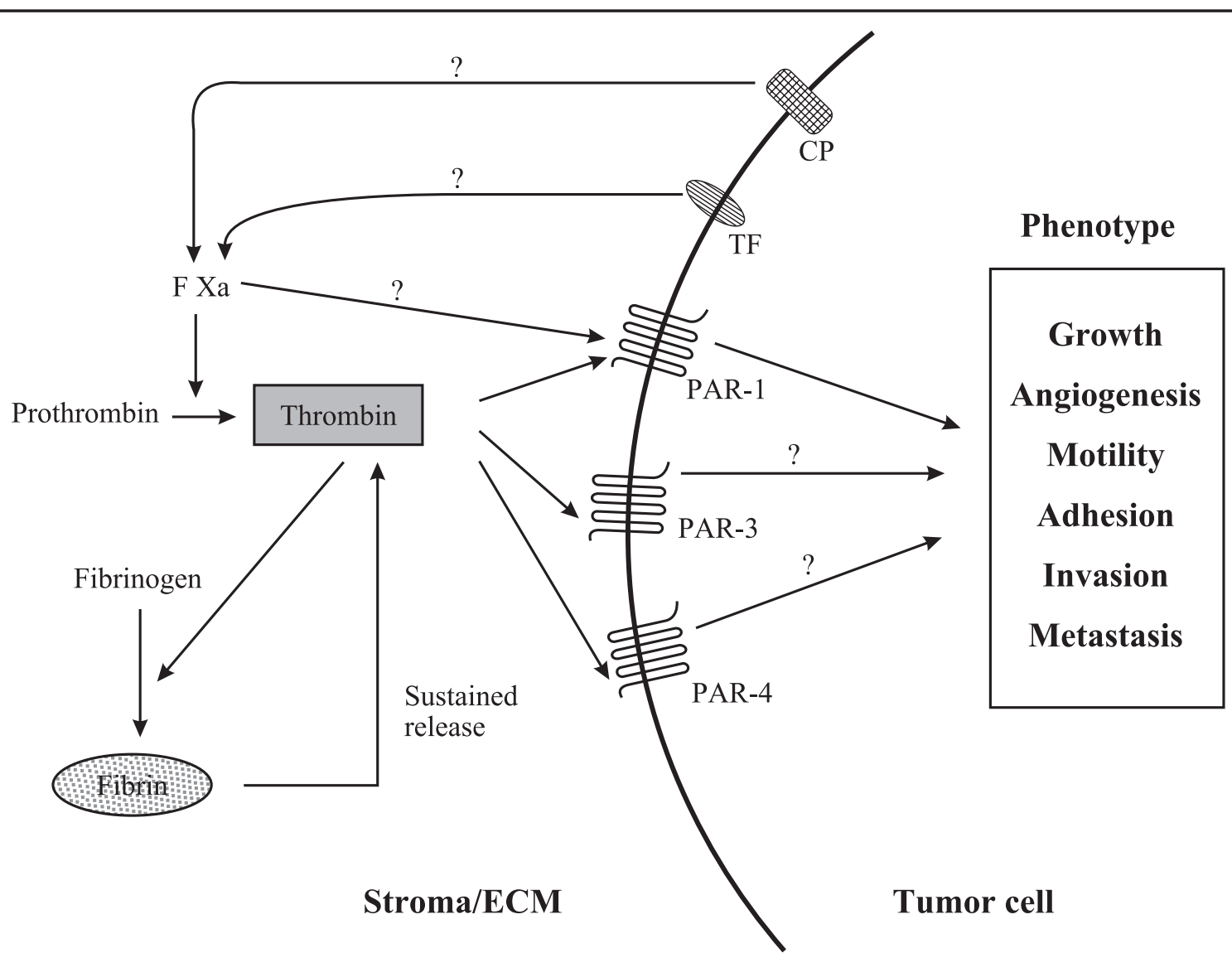

Figure 2. Local generation of thrombin and its modulating effects on the tumor phenotype via activation of thrombin receptor(s) expressed by malignant cells (PAR, protease-activated receptor; ECM, extracellular matrix; TF, tissue factor; $C P$, cancer procoagulant).

tasis $(44,133,134)$. New approaches are continuously being used with the attempt to target the cellular thrombin-PAR interface. A detailed understanding of the association between thrombin receptor and cancer may give rise to new therapeutic approaches consisting of the suppression of thrombin receptor(s) in cancer.

\section{ACKNOWLEDGMENT}

Original work presented in this review was supported by grant GRK 19/3-02 administered through the Deutsche Forschungsgemeinschaft (Bonn, Germany) to Jian Liu. We wish to thank all staff members of the research laboratories at the authors' institution for ongoing excellent technical support and scientific dispute.

\section{REFERENCES}

1. Hanahan D, Weinberg RA. The hallmarks of cancer. Cell 2000; 100: 57-70.

2. Stubbs MT, Bode W. A model for the specificity of fi- brinogen cleavage by thrombin. Semin Thromb Hemost 1993; 19: 344-351.

3. Mann $\mathrm{KG}$, Brummel $\mathrm{K}$, Butenas $\mathrm{S}$. What is all that thrombin for? J Thromb Haemost 2003; 1: 1504-1514.

4. Chen LB, Buchanan JM. Mitogenic activity of blood components. I. Thrombin and prothrombin. Proc Natl Acad Sci USA 1975; 72: 131-135.

5. Glenn KC, Carney DH, Fenton JW $2^{\text {nd }}$, Cunningham DD. Thrombin active site regions required for fibroblast receptor binding and initiation of cell division. $J$ Biol Chem 1980; 255: 6609-6616.

6. LaMorte VJ, Kennedy ED, Collins LR, Goldstein D, Harootunian AT, Brown $\mathrm{JH}$, et al. A requirement for Ras protein function in thrombin-stimulated mitogenesis in astrocytoma cells. J Biol Chem 1993; 268: 19411-19415.

7. Guttridge DC, Lau A, Tran L, Cunningham DD. Thrombin causes a marked delay in skeletal myogenesis that correlates with the delayed expression of myogenin and p21CIP1/WAF1. J Biol Chem 1997; 272: 
24117-24120.

8. Derian CK, Eckardt AJ. Thrombin receptor-dependent prostaglandin E2 synthesis in hamster fibroblasts: synergistic interactions with interleukin-1beta. Exp Cell Res 1997; 232: 1-7.

9. Rickles FR, Levine MN. Epidemiology of thrombosis in cancer. Acta Haematol 2001; 106: 6-12.

10. Lip GY, Chin BS, Blann AD. Cancer and the prothrombotic state. Lancet Oncol 2002; 3: 27-34.

11. Deitcher SR. Cancer-related deep venous thrombosis: clinical importance, treatment challenges, and management strategies. Semin Thromb Hemost 2003; 29: 247258 .

12. van Wersch JW, Tjwa MK. Coagulation/fibrinolysis balance and lung cancer. Haemostasis 1991; 21: 117123.

13. Gabazza EC, Taguchi O, Yamakami T, Machishi M, Ibata H, Suzuki S. Evaluating prethrombotic state in lung cancer using molecular markers. Chest 1993; 103: 196-200.

14. van Duijnhoven EM, Lustermans FA, van Wersch JW. Evaluation of the coagulation/fibrinolysis balance in patients with colorectal cancer. Haemostasis 1993; 23: 168-172.

15. von Tempelhoff GF, Dietrich M, Niemann F, Schneider D, Hommel G, Heilmann L. Blood coagulation and thrombosis in patients with ovarian malignancy. Thromb Haemost 1997; 77: 456-461.

16. Kohli M, Kaushal V, Mehta P. Role of coagulation and fibrinolytic system in prostate cancer. Semin Thromb Hemost 2003; 29: 301-308.

17. Geenen RW, Delaere KP, van Wersch JW. Coagulation and fibrinolysis activation markers in prostatic carcinoma patients. Eur J Clin Chem Clin Biochem 1997; 35: 69-72.

18. Kohli M, Fink LM, Spencer HJ, Zent CS. Advanced prostate cancer activates coagulation: a controlled study of activation markers of coagulation in ambulatory patients with localized and advanced prostate cancer. Blood Coagul Fibrinol 2002; 13: 1-5.

19. Gouin-Thibault I, Achkar A, Samama MM. The thrombophilic state in cancer patients. Acta Haematol 2001; 106: 33-42.

20. Wojtukiewicz MZ, Rucinska M, Zimnoch L, Jaromin J, Piotrowski Z, Rozanska-Kudelska M, et al. Expression of prothrombin fragment $1+2$ in cancer tissue as an indicator of local activation of blood coagulation. Thromb Res 2000; 97: 335-342.

21. Lind SE, Caprini JA, Goldshteyn S, Dohnal JC, Vesely SK, Shevrin DH. Correlates of thrombin generation in patients with advanced prostate cancer. Thromb Haemost 2003; 89: 185-189.
22. Wojtukiewicz MZ, Rucinska M, Zacharski LR, Kozlowski L, Zimnoch L, Piotrowski Z, et al. Localization of blood coagulation factors in situ in pancreatic carcinoma. Thromb Haemost 2001; 86: 1416-1420.

23. Zacharski LR, Memoli VA, Morain WD, Schlaeppi JM, Rousseau SM. Cellular localization of enzymatically active thrombin in intact human tissues by hirudin binding. Thromb Haemost 1995; 73: 793-797.

24. Francis CW, Markham RE Jr, Barlow GH, Florack TM, Dobrzynski DM, Marder VJ. Thrombin activity of fibrin thrombi and soluble plasmic derivatives. $J$ Lab Clin Med 1983; 102: 220-230.

25. Wojtukiewicz MZ, Zacharski LR, Memoli VA, Kisiel W, Kudryk BJ, Moritz TE, et al. Fibrin formation on vessel walls in hyperplastic and malignant prostate tissue. Cancer 1991; 67: 1377-1383.

26. Costantini V, Zacharski LR. Fibrin and cancer. Thromb Haemost 1993; 69: 406-414.

27. Idell S, Pueblitz S, Emri S, Gungen Y, Gray L, Kumar A, et al. Regulation of fibrin deposition by malignant mesothelioma. Am J Pathol 1995; 147: 1318-1329.

28. Bardos H, Juhasz A, Repassy G, Adany R. Fibrin deposition in squamous cell carcinomas of the larynx and hypopharynx. Thromb Haemost 1998; 80: 767-772.

29. Nagy JA, Brown LF, Senger DR, Lanir N, Van de Water L, Dvorak AM, et al. Pathogenesis of tumor stroma generation: a critical role for leaky blood vessels and fibrin deposition. Biochim Biophys Acta 1989; 948: 305-326.

30. Simpson-Haidaris PJ, Rybarczyk B. Tumors and fibrinogen. The role of fibrinogen as an extracellular matrix protein. Ann NY Acad Sci 2001; 936: 406-425.

31. Idell S, Mazar AP, Bitterman P, Mohla S, Harabin AL. Fibrin turnover in lung inflammation and neoplasia. Am J Respir Crit Care Med 2001; 163: 578-584.

32. Gandossi E, Lunven C, Berry CN. Role of clot-associated (-derived) thrombin in cell proliferation induced by fibrin clots in vitro. $B r J$ Pharmacol 2000; 129: 1021-1027.

33. Wilner GD, Danitz MP, Mudd MS, Hsieh KH, Fenton JW $2^{\text {nd }}$. Selective immobilization of alpha-thrombin by surface-bound fibrin. J Lab Clin Med 1981; 97: 403411.

34. Gether U. Uncovering molecular mechanisms involved in activation of $\mathrm{G}$ protein-coupled receptors. Endocr Rev 2000; 21: 90-113.

35. Vu TK, Hung DT, Wheaton VI, Coughlin SR. Molecular cloning of a functional thrombin receptor reveals a novel proteolytic mechanism of receptor activation. Cell 1991; 64: 1057-1068.

36. Coughlin SR. Thrombin signalling and protease-activated receptors. Nature 2000; 407: 258-264. 
37. Nystedt S, Emilsson K, Wahlestedt C, Sundelin J. Molecular cloning of a potential proteinase activated receptor. Proc Natl Acad Sci USA 1994; 91: 9208-9212.

38. Riewald M, Kravchenko VV, Petrovan RJ, O'Brien PJ, Brass LF, Ulevitch RJ, et al. Gene induction by coagulation factor $\mathrm{Xa}$ is mediated by activation of proteaseactivated receptor 1. Blood 2001; 97: 3109-3116.

39. Camerer E, Huang W, Coughlin SR. Tissue factor- and factor X-dependent activation of protease-activated receptor 2 by factor VIIa. Proc Natl Acad Sci USA 2000; 97: 5255-5260.

40. Cupit LD, Schmidt VA, Bahou WF. Proteolytically activated receptor-3. A member of an emerging gene family of protease receptors expressed on vascular endothelial cells and platelets. Trends Cardiovasc Med 1999; 9: 42-48.

41. Xu WF, Andersen H, Whitmore TE, Presnell SR, Yee DP, Ching A, et al. Cloning and characterization of human protease-activated receptor 4. Proc Natl Acad Sci USA 1998; 95: 6642-6646.

42. Trejo J, Altschuler Y, Fu HW, Mostov KE, Coughlin SR. Protease-activated receptor-1 down-regulation: a mutant HeLa cell line suggests novel requirements for PAR1 phosphorylation and recruitment to clathrincoated pits. J Biol Chem 2000; 275: 31255-31265.

43. Woolkalis MJ, DeMelfi TM Jr, Blanchard N, Hoxie JA, Brass LF. Regulation of thrombin receptors on human umbilical vein endothelial cells. J Biol Chem 1995; 270: 9868-9875.

44. Macfarlane SR, Seatter MJ, Kanke T, Hunter GD, Plevin R. Proteinase-activated receptors. Pharmacol Rev 2001; 53: 245-282.

45. Hou L, Howells GL, Kapas S, Macey MG. The protease-activated receptors and their cellular expression and function in blood-related cells. $\mathrm{Br} J$ Haematol 1998; 101: 1-9.

46. Weinstein JR, Gold SJ, Cunningham DD, Gall CM. Cellular localization of thrombin receptor mRNA in rat brain: expression by mesencephalic dopaminergic neurons and codistribution with prothrombin mRNA. $J$ Neurosci 1995; 15: 2906-2919.

47. Ishihara H, Zeng D, Connolly AJ, Tam C, Coughlin SR. Antibodies to protease-activated receptor 3 inhibit activation of mouse platelets by thrombin. Blood 1998; 91: 4152-4157.

48. Hauck RW, Schulz C, Schomig A, Hoffman RK, Panettieri RA Jr. alpha-Thrombin stimulates contraction of human bronchial rings by activation of protease-activated receptors. Am J Physiol 1999; 277: L22-29.

49. Bartha K, Domotor E, Lanza F, Adam-Vizi V, Machovich $\mathrm{R}$. Identification of thrombin receptors in rat brain capillary endothelial cells. J Cereb Blood Flow Metab
2000; 20: 175-182.

50. Kahn ML, Nakanishi-Matsui M, Shapiro MJ, Ishihara $\mathrm{H}$, Coughlin SR. Protease-activated receptors 1 and 4 mediate activation of human platelets by thrombin. $J$ Clin Invest 1999; 103: 879-887.

51. Major CD, Santulli RJ, Derian CK, Andrade-Gordon P. Extracellular mediators in atherosclerosis and thrombosis: lessons from thrombin receptor knockout mice. Arterioscler Thromb Vasc Biol 2003; 23: 931-939.

52. Liu Y, Gilcrease MZ, Henderson Y, Yuan XH, Clayman GL, Chen Z. Expression of protease-activated receptor 1 in oral squamous cell carcinoma. Cancer Lett 2001; 169: 173-180.

53. Rudroff C, Seibold S, Kaufmann R, Zetina CC, Reise $\mathrm{K}$, Schafer U, et al. Expression of the thrombin receptor PAR-1 correlates with tumour cell differentiation of pancreatic adenocarcinoma in vitro. Clin Exp Metastasis 2002; 19: 181-189.

54. Chay $\mathrm{CH}$, Cooper CR, Gendernalik JD, Dhanasekaran SM, Chinnaiyan AM, Rubin MA, et al. A functional thrombin receptor (PAR1) is expressed on bone-derived prostate cancer cell lines. Urology 2002; 60: 760765.

55. Cooper CR, Chay CH, Gendernalik JD, Lee HL, Bhatia J, Taichman RS, et al. Stromal factors involved in prostate carcinoma metastasis to bone. Cancer 2003; 97: S739-747.

56. D'Andrea MR, Derian CK, Santulli RJ, Andrade-Gordon P. Differential expression of protease-activated receptors- 1 and -2 in stromal fibroblasts of normal, benign, and malignant human tissues. Am J Pathol 2001; 158: 2031-2041.

57. Kaufmann R, Patt S, Zieger M, Kraft R, Tausch S, Henklein $\mathrm{P}$, et al. The two-receptor system PAR-1/ PAR-4 mediates $\alpha$-thrombin-induced $\left[\mathrm{Ca}^{2+}\right]_{i}$ mobilization in human astrocytoma cells. J Cancer Res Clin Oncol 2000; 126: 91-94.

58. Kaufmann R, Junker U, Nuske K, Westermann M, Henklein P, Scheele J, et al. PAR-1- and PAR-3-type thrombin receptor expression in primary cultures of human renal cell carcinoma cells. Int J Oncol 2002; 20: 177-180.

59. Kamath L, Meydani A, Foss F, Kuliopulos A. Signaling from protease-activated receptor-1 inhibits migration and invasion of breast cancer cells. Cancer Res 2001; 61: 5933-5940.

60. Bromberg ME, Bailly MA, Konigsberg WH. Role of protease-activated receptor 1 in tumor metastasis promoted by tissue factor. Thromb Haemost 2001; 86: 1210-1214.

61. Even-Ram S, Uziely B, Cohen P, Grisaru-Granovsky S, Maoz M, Ginzburg Y, et al. Thrombin receptor 
overexpression in malignant and physiological invasion processes. Nat Med 1998; 4: 909-914.

62. Henrikson KP, Salazar SL, Fenton JW 2nd, Pentecost BT. Role of thrombin receptor in breast cancer invasiveness. Br J Cancer 1999; 79: 401-406.

63. Huang YQ, Li JJ, Karpatkin S. Thrombin inhibits tumor cell growth in association with up-regulation of $\mathrm{p} 21^{\text {(waf/cipl) }}$ and caspases via a p53-independent, STAT1-dependent pathway. J Biol Chem 2000; 275: 64626468.

64. Greenberg DL, Mize GJ, Takayama TK. Protease-activated receptor mediated RhoA signaling and cytoskeletal reorganization in LNCaP cells. Biochemistry 2003; 42: 702-709.

65. Liu J, Bastian M, Kohlschein P, Schuff-Werner P, Steiner M. Expression of functional protease-activated receptor 1 in human prostate cancer cell lines. Urol Res 2003; 31: 163-168.

66. Okamoto T, Nishibori M, Sawada K, Iwagaki H, Nakaya N, Jikuhara A, et al. The effects of stimulating protease-activated receptor-1 and -2 in A172 human glioblastoma. J Neural Transm 2001; 108: 125-140.

67. Fischer EG, Ruf W, Mueller BM. Tissue factor-initiated thrombin generation activates the signaling thrombin receptor on malignant melanoma cells. Cancer Res 1995; 55: 1629-1632.

68. Nierodzik ML, Bain RM, Liu LX, Shivji M, Takeshita $\mathrm{K}$, Karpatkin S. Presence of the seven transmembrane thrombin receptor on human tumour cells: effect of activation on tumour adhesion to platelets and tumor tyrosine phosphorylation. Br J Haematol 1996; 92: 452-457.

69. Asokananthan N, Graham PT, Fink J, Knight DA, Bakker AJ, McWilliam AS, et al. Activation of proteaseactivated receptor (PAR)-1, PAR-2, and PAR-4 stimulates IL-6, IL-8, and prostaglandin E2 release from human respiratory epithelial cells. J Immunol 2002; 168: 3577-3585.

70. Kaufmann R, Schafberg H, Rudroff C, Nowak G. Thrombin receptor activation results in calcium signaling and protein kinase $\mathrm{C}$-dependent stimulation of DNA synthesis in HEp-2g laryngeal carcinoma cells. Cancer 1997; 80: 2068-2074.

71. Rudroff C, Schafberg H, Nowak G, Weinel R, Scheele J, Kaufmann R. Characterization of functional thrombin receptors in human pancreatic tumor cells (MIA PACA-2). Pancreas 1998; 16: 189-194.

72. Lourbakos A, Potempa J, Travis J, D'Andrea MR, Andrade-Gordon P, Santulli R, et al. Arginine-specific protease from Porphyromonas gingivalis activates protease-activated receptors on human oral epithelial cells and induces interleukin-6 secretion. Infect Immun
2001; 69: 5121-5130.

73. Wojtukiewicz MZ, Tang DG, Ben-Josef E, Renaud C, Walz DA, Honn KV. Solid tumor cells express functional "tethered ligand" thrombin receptor. Cancer Res 1995; 55: 698-704.

74. Kaufmann R, Patt S, Schafberg H, Kalff R, Neupert $\mathrm{G}$, Nowak G. Functional thrombin receptor PAR1 in primary cultures of human glioblastoma cells. Neuroreport 1998; 9: 709-712.

75. Masters J. False cell lines. Carcinogenesis 2002; 23: 371.

76. Ordonez NG. Thrombomodulin expression in transitional cell carcinoma. Am J Clin Pathol 1998; 110: 385-390.

77. Oleksowicz L, Dutcher JP, DeLeon-Fernandez M, Etkind P. A GPIb alpha-related protein is expressed by fresh human breast carcinoma tissue and is regulated by a PKC-sensitive mechanism. Exp Cell Res 1997; 237: 110-117.

78. Sadler JE. Thrombomodulin structure and function. Thromb Haemost 1997; 78: 392-395.

79. Ruf W. PAR1 signaling: more good than harm? Nat Med 2003; 9: 258-260.

80. Tezuka Y, Yonezawa S, Maruyama I, Matsushita Y, Shimizu T, Obama H, et al. Expression of thrombomodulin in esophageal squamous cell carcinoma and its relationship to lymph node metastasis. Cancer Res 1995; 55: 4196-4200.

81. Wilhelm S, Schmitt M, Parkinson J, Kuhn W, Graeff H, Wilhelm OG. Thrombomodulin, a receptor for the serine protease thrombin, is decreased in primary tumors and metastases but increased in ascitic fluids of patients with advanced ovarian cancer FIGO IIIc. Int $J$ Oncol 1998; 13: 645-651.

82. Oikawa T, Kushuhara M, Ishikawa S, Hitomi J, Kono A, Iwanaga T, et al. Production of endothelin-1 and thrombomodulin by human pancreatic cancer cells. $\mathrm{Br}$ J Cancer 1994; 69: 1059-1064.

83. Ogawa H, Yonezawa S, Maruyama I, Matsushita Y, Tezuka Y, Toyoyama H, et al. Expression of thrombomodulin in squamous cell carcinoma of the lung: its relationship to lymph node metastasis and prognosis of the patients. Cancer Lett 2000; 149: 95-103.

84. Tamura A, Hebisawa A, Hayashi K, Sagara Y, Fukushima K, Kurashima A, et al. Prognostic significance of thrombomodulin expression and vascular invasion in stage I squamous cell carcinoma of the lung. Lung Cancer 2001; 34: 375-382.

85. Maruyama I, Majerus PW. The turnover of thrombinthrombomodulin complex in cultured human umbilical vein endothelial cells and A549 lung cancer cells. Endocytosis and degradation of thrombin. J Biol Chem 
1985; 260: 15432-15438.

86. Berndt MC, Shen Y, Dopheide SM, Gardiner EE, Andrews RK. The vascular biology of the glycoprotein Ib-IX-V complex. Thromb Haemost 2001; 86: 178188.

87. De Candia E, Hall SW, Rutella S, Landolfi R, Andrews RK, De Cristofaro R. Binding of thrombin to glycoprotein $\mathrm{Ib}$ accelerates the hydrolysis of Par-1 on intact platelets. J Biol Chem 2001; 276: 4692-4698.

88. Kaushansky K. The mpl ligand: molecular and cellular biology of the critical regulator of megakaryocyte development. Stem Cells 1994; 12: S91-96.

89. Nierodzik ML, Chen K, Takeshita K, Li JJ, Huang YQ, Feng XS, et al. Protease-activated receptor 1 (PAR-1) is required and rate-limiting for thrombin-enhanced experimental pulmonary metastasis. Blood 1998; 92: 3694-3700.

90. Oleksowicz L, Mrowiec Z, Schwartz E, Khorshidi M, Dutcher JP, Puszkin E. Characterization of tumor-induced platelet aggregation: the role of immunorelated GPIb and GPIIb/ IIIa expression by MCF-7 breast cancer cells. Thromb Res 1995; 79: 261-274.

91. Suter CM, Hogg PJ, Price JT, Chong BH, Ward RL. Identification and characterisation of a platelet GPIb/ V/IX-like complex on human breast cancers: implications for the metastatic process. Jpn J Cancer Res 2001; 92: 1082-1092.

92. Borrelli V, Sterpetti AV, Coluccia P, Randone B, Cavallaro A, D'Angelo LS, et al. Bimodal concentrationdependent effect of thrombin on endothelial cell proliferation and growth factor release in culture. J Surg Res 2001; 100: 154-160.

93. Simon A, Brockes JP. Thrombin activation of S-phase reentry by cultured pigmented epithelial cells of adult newt iris. Exp Cell Res 2002; 281: 101-106.

94. Naldini A, Carney DH, Pucci A, Carraro F. Human alpha-thrombin stimulates proliferation of interferongamma differentiated, growth-arrested U937 cells, overcoming differentiation-related changes in expression of p21CIP1/WAF1 and cyclin D1. J Cell Physiol 2002; 191: 290-297.

95. Darmoul D, Gratio V, Devaud H, Lehy T, Laburthe M. Aberrant expression and activation of the thrombin receptor protease-activated receptor-1 induces cell proliferation and motility in human colon cancer cells. Am $J$ Pathol 2003; 162: 1503-1513.

96. Schramek H. MAP kinases: from intracellular signals to physiology and disease. News Physiol Sci 2002; 17: 62-67.

97. Zain J, Huang YQ, Feng X, Nierodzik ML, Li JJ, Karpatkin S. Concentration-dependent dual effect of thrombin on impaired growth/apoptosis or mitogenesis in tumor cells. Blood 2000; 95: 3133-3138.

98. Ahmad R, Knafo L, Xu J, Sindhu ST, Menezes J, Ah$\operatorname{mad} \mathrm{A}$. Thrombin induces apoptosis in human tumor cells. Int J Cancer 2000; 87: 707-715.

99. Schafberg H, Nowak G, Kaufmann R. Thrombin has a bimodal effect on glioma cell growth. Br J Cancer 1997; 76: 1592-1595.

100. Ahmad R, Menezes J, Ahmad A. Signaling mechanism in the induction of apoptosis by thrombin in human tumor cells. Blood 2000; 96: 4001.

101. Maragoudakis ME, Tsopanoglou NE, Andriopoulou P. Mechanism of thrombin-induced angiogenesis. Biochem Soc Trans 2002; 30: 173-177.

102. Sampson MT, Kakkar AK. Coagulation proteases and human cancer. Biochem Soc Trans 2002; 30: 201-207.

103. Yin YJ, Salah Z, Maoz M, Ram SC, Ochayon S, Neufeld G, et al. Oncogenic transformation induces tumor angiogenesis: a role for PAR1 activation. FASEB J 2003; 17: 163-174.

104. Dvorak HF. How tumors make bad blood vessels and stroma. Am J Pathol 2003; 162: 1747-1757.

105. Mazzucchelli R, Montironi R, Santinelli A, Lucarini G, Pugnaloni A, Biagini G. Vascular endothelial growth factor expression and capillary architecture in high-grade PIN and prostate cancer in untreated and androgen-ablated patients. Prostate 2000; 45: 72-79.

106. Huang YQ, Li JJ, Hu L, Lee M, Karpatkin S. Thrombin induces increased expression and secretion of VEGF from human FS4 fibroblasts, DU145 prostate cells and CHRF megakaryocytes. Thromb Haemost 2001; 86: 1094-1098.

107. Bassus S, Herkert O, Kronemann N, Gorlach A, Bremerich D, Kirchmaier CM, et al. Thrombin causes vascular endothelial growth factor expression in vascular smooth muscle cells: role of reactive oxygen species. Arterioscler Thromb Vasc Biol 2001; 21: 1550-1555.

108. Zucker S, Mirza H, Conner CE, Lorenz AF, Drews MH, Bahou WF, et al. Vascular endothelial growth factor induces tissue factor and matrix metalloproteinase production in endothelial cells: conversion of prothrombin to thrombin results in progelatinase A activation and cell proliferation. Int J Cancer 1998; 75: 780-786.

109. Senger DR, Van de Water L, Brown LF, Nagy JA, Yeo $\mathrm{KT}$, Yeo TK, et al. Vascular permeability factor (VPF, VEGF) in tumor biology. Cancer Metastasis Rev 1993; 12: 303-324.

110. Hahn D, Simak R, Steiner GE, Handisurya A, Susani M, Marberger M. Expression of the VEGF-receptor Flt-1 in benign, premalignant and malignant prostate tissues. J Urol 2000; 164: 506-510.

111. Arenberg DA, Kunkel SL, Polverini PJ, Glass M, Burdick MD, Strieter RM. Inhibition of interleukin-8 re- 
duces tumorigenesis of human non-small cell lung cancer in SCID mice. J Clin Invest 1996; 97: 2792-2802.

112. Moore BB, Arenberg DA, Stoy K, Morgan T, Addison CL, Morris SB, et al. Distinct CXC chemokines mediate tumorigenicity of prostate cancer cells. Am J Pathol 1999; 154: 1503-1512.

113. Li A, Dubey S, Varney ML, Dave BJ, Singh RK. IL8 directly enhanced endothelial cell survival, proliferation, and matrix metalloproteinases production and regulated angiogenesis. J Immunol 2003; 170: 33693376.

114. Lalla RV, Goralnick SJ, Tanzer ML, Kreutzer DL. Fibrin induces IL-8 expression from human oral squamous cell carcinoma cells. Oral Oncol 2001; 37: 234242.

115. Davis S, Aldrich TH, Jones PF, Acheson A, Compton $\mathrm{DL}$, Jain $\mathrm{V}$, et al. Isolation of angiopoietin-1, a ligand for the TIE2 receptor, by secretion-trap expression cloning. Cell 1996; 87: 1161-1169.

116. Huang YQ, Li JJ, Hu L, Lee M, Karpatkin S. Thrombin induces increased expression and secretion of angiopoietin-2 from human umbilical vein endothelial cells. Blood 2002; 99: 1646-1650.

117. Martins-Green M, Hanafusa H. The 9E3/CEF4 gene and its product the chicken chemotactic and angiogenic factor (cCAF): potential roles in wound healing and tumor development. Cytokine Growth Factor Rev 1997; 8: 221-232.

118. Bussolati B, Biancone L, Cassoni P, Russo S, RolaPleszczynski M, Montrucchio G, et al. PAF produced by human breast cancer cells promotes migration and proliferation of tumor cells and neo-angiogenesis. Am J Pathol 2000; 157: 1713-1725.

119. Nierodzik ML, Klepfish A, Karpatkin S. Role of platelets, thrombin, integrin IIb-IIIa, fibronectin and von Willebrand factor on tumor adhesion in vitro and metastasis in vivo. Thromb Haemost 1995; 74: 282-290.

120. Rudroff C, Striegler S, Schilli M, Scheele J. Thrombin enhances adhesion in pancreatic cancer in vitro through the activation of the thrombin receptor PAR 1. Eur J Surg Oncol 2001; 27: 472-476.

121. Kaplanski G, Marin V, Fabrigoule M, Boulay V, Benoliel AM, Bongrand P, et al. Thrombin-activated human endothelial cells support monocyte adhesion in vitro following expression of intercellular adhesion molecule-1 (ICAM-1; CD54) and vascular cell adhesion molecule-1 (VCAM-1; CD106). Blood 1998; 92: 1259-1267.

122. Even-Ram SC, Maoz M, Pokroy E, Reich R, Katz BZ, Gutwein $\mathrm{P}$, et al. Tumor cell invasion is promoted by activation of protease activated receptor-1 in cooperation with the $\alpha_{\mathrm{v}} \beta_{5}$ integrin. $J$ Biol Chem 2001; 276: 10952-10962.

123. Dardik R, Savion N, Kaufmann Y, Varon D. Thrombin promotes platelet-mediated melanoma cell adhesion to endothelial cells under flow conditions: role of platelet glycoproteins P-selectin and GPIIb-IIIA. Br J Cancer 1998; 77: 2069-2075.

124. Mareel M, Leroy A. Clinical, cellular, and molecular aspects of cancer invasion. Physiol Rev 2003; 83: 337376.

125. Yoshida E, Verrusio EN, Mihara H, Oh D, Kwaan HC. Enhancement of the expression of urokinase-type plasminogen activator from PC-3 human prostate cancer cells by thrombin. Cancer Res 1994; 54: 3300-3304.

126. Benezra M, Vlodavsky I, Bar-Shavit R. Thrombin enhances degradation of heparan sulfate in the extracellular matrix by tumor cell heparanase. Exp Cell Res 1992; 201: 208-215.

127. Vlodavsky I, Friedmann Y. Molecular properties and involvement of heparanase in cancer metastasis and angiogenesis. J Clin Invest 2001; 108: 341-347.

128. Yin YJ, Salah Z, Grisaru-Granovsky S, Cohen I, EvenRam SC, Maoz M, et al. Human protease-activated receptor 1 expression in malignant epithelia: a role in invasiveness. Arterioscler Thromb Vasc Biol 2003; 23: 940-944.

129. Bastida E, Ordinas A, Escolar G, Jamieson GA. Tissue factor in microvesicles shed from U87MG human glioblastoma cells induces coagulation, platelet aggregation, and thrombogenesis. Blood 1984; 64: 177-184.

130. Heinmoller E, Schropp T, Kisker O, Simon B, Seitz R, Weinel RJ. Tumor cell-induced platelet aggregation in vitro by human pancreatic cancer cell lines. Scand $J$ Gastroenterol 1995; 30: 1008-1016.

131. Rohrer DK, Kobilka BK. G protein-coupled receptors: functional and mechanistic insights through altered gene expression. Physiol Rev 1998; 78: 35-52.

132. Elbashir SM, Harborth J, Weber K, Tuschl T. Analysis of gene function in somatic mammalian cells using small interfering RNAs. Methods 2002; 26: 199-213.

133. Covic L, Gresser AL, Talavera J, Swift S, Kuliopulos A. Activation and inhibition of $G$ protein-coupled receptors by cell-penetrating membrane-tethered peptides. Proc Natl Acad Sci USA 2002; 99: 643-648.

134. Seiler SM, Bernatowicz MS. Peptide-derived proteaseactivated receptor-1 (PAR-1) antagonists. Curr Med Chem Cardiovasc Hematol Agents 2003; 1: 1-11. 